\title{
Delineation of Potential Groundwater Zone Using RS and GIS: A Review
}

\author{
Laulina Kumari* \\ Division of Agricultural Engineering, ICAR-Indian Agricultural Research Institute, \\ New Delhi-110012, India \\ *Corresponding author
}

\section{A B S T R A C T}

\section{Keywords \\ Delineation, \\ Groundwater, \\ Topography, Thematic \\ map, Remote sensing, \\ GIS}

\section{Article Info}

Accepted:

xx November 2018

Available Online:

xx December 2018
Water is one of the most essential commodities for mankind and the largest available source of fresh water lays underground. Tremendous increase in the agricultural, industrial and domestic activities in recent years has increased the demand for good quality water to meet the growing needs. Groundwater is mostly preferred to meet this growing demand because of its lower level of contamination and wider distribution. The occurrence of groundwater is a consequence of the interaction of the climatic, geological, hydrological and physiographical factors. The surface hydrological features like topography, geomorphology, drainage, surface water bodies, etc. play important role in groundwater replenishment. Hence, identification and quantization of these features are important in generating groundwater potential model of a particular area. Remote sensing is an excellent tool for hydrologists and geologists in understanding the perplexing problems of groundwater exploration. In recent years, Satellite remote sensing data has been widely used in locating groundwater potential zones. Satellite remote sensing data is not only cost effective, reliable and timely but also meets the essential requirements of data in the geographical Information System (GIS) domain, which are "current, sufficiently accurate, comprehensive and available to a uniform standard". Integration of the information on the controlling parameters is best achieved through GIS which is an effective tool for storage, management and retrieval of spatial and non-spatial data. Satellite data have been used to prepare various thematic maps, viz., geomorphological, geological, slope, drainage density, lineament density map. On the basis of relative contribution of each of these maps towards groundwater potential, the weight of each thematic map has been selected. Further, within each thematic map ranking has been made for each of the features. All the thematic maps have been registered with one another through ground control points and integrated step by step using the GIS for computing groundwater potential index. On the basis of this final weight and ranking, the ground water potential zones have been delineated. The groundwater potential zones are classified into five categories like very poor, poor, moderate, good and very good. This groundwater potential information is useful for effective identification of suitable locations for extraction of water. Thus, it is observed that an integrated approach involving remote sensing and GIS technique can be successfully used in identifying potential groundwater zones. 


\section{Introduction}

Water is one of the most essential commodities for mankind and the largest available source of fresh water lays underground. It is one of the most significant natural resources which support both human needs and economic development. Tremendous increase in the agricultural, industrial and domestic activities in recent years has increased the demand for good quality water to meet the growing needs. Groundwater is mostly preferred to meet this growing demand because of its lower level of contamination and wider distribution.

The Annual Replenishable Ground Water Resource for the entire country is 433 billion cubic metres (bcm). The Annual Replenishable Ground Water Resource is contributed by two major sources viz. rainfall and other sources that include canal seepage return flow from irrigation, seepage from water bodies and artificial recharge due to water conservation structures. The overall contribution of rainfall to country's annual replenishable ground water resource is $67 \%$ and the share of other sources taken together is $33 \%$.

The contribution from other sources such as canal seepage, return flow from irrigation, seepage from water bodies etc in annual replenishable resources is more than of 33\% in the states of Andhra Pradesh, Delhi, Haryana, Jammu \& Kashmir, Jharkhand, Punjab, Tamil Nadu, Uttar Pradesh, Uttaranchal and UT of Pondicherry.

South-west monsoon being the most prevalent contributor of rainfall in the country, about $73 \%$ of country's annual replenishable ground water recharge takes place during the kharif period of cultivation. Keeping $34 \mathrm{bcm}$ for natural discharge, the net ground water available for utilization for the entire country is $399 \mathrm{bcm}$. The annual ground water draft is $231 \mathrm{bcm}$, out of which $213 \mathrm{bcm}$ is for irrigation use and $18 \mathrm{bcm}$ for domestic \& industrial use.

\section{Why need mapping of groundwater potential zone?}

Proper groundwater delineation is necessary for exploration, proper planning, Sustainable utilization and Management of groundwater resources.

There is no direct method to facilitate observation of water below the surface.

Presence or absence of groundwater can only inferred by studying geological and surface hydrological parameters.

Surface hydrological features like topography, geomorphology, drainage, surface water bodies play important role in groundwater replenishment.

Hence, identification and quantization of these features are important in generating groundwater potential model.

Remote sensing and GIS techniques have emerged as a very effective and reliable tool in the assessment, monitoring and conservation of groundwater resources.

The movement of groundwater is controlled mainly by porosity and permeability of the surface and underlying lithology. The same lithology forming different geomorphic units will have variable porosity and permeability thereby causing changes in the potential of groundwater. This is also true for same geomorphic units with variable lithology. The surface hydrological features like topography, geomorphology, drainage, surface water bodies, etc. play important role in groundwater replenishment. High relief and steep slopes 
impart higher runoff, while the topographical depressions help in an increased infiltration. An area of high drainage density also increases surface runoff compared to a low drainage density area. Surface water bodies like rivers, ponds, etc. can act as a recharge zones enhancing the groundwater potential in the vicinity. Hence, identification and quantization of these features are important in generating groundwater potential model of a particular area.

The occurrence of groundwater at any place on the earth is not a matter of chance but a consequence of the interaction of the climatic, geological, hydrological, physiographical and ecological factors. Groundwater exploration operation is essentially a hydrogeological and geophysical inference operation and is dependent on the correct interpretation of the hydrological indicators and evidences.

\section{Remote sensing and GIS in water resources}

Remote sensing is an excellent tool for hydrologists and geologists in understanding the "perplexing" problems of groundwater exploration. In recent years, Satellite remote sensing data has been widely used in locating groundwater potential zones. Satellite remote sensing data is not only cost effective, reliable and timely but also meets the essential requirements of data in the geographical Information System (GIS) domain, which are "current, sufficiently accurate, comprehensive and available to a uniform standard". Integration of the information on the controlling parameters is best achieved through GIS which is an effective tool for storage, management and retrieval of spatial and non-spatial data as well as for integration and analysis of this information for meaningful solutions. The technique of integration of remote sensing and GIS has proved to be extremely useful for groundwater studies.
Satellite remote sensing provides an opportunity for better observation and more systematic analysis of various geomorphic units/landforms/lineaments due to the synoptic and multi-spectral coverage of a terrain. Investigation of remotely sensed data for drainage map, geological, geomorphological and lineament characteristics of terrain in an integrated way facilitate effective evaluation of ground water potential zones. Similar attempts have been made in the generation of different thematic maps for the delineation of groundwater potential zones in different parts of the country. Analysis of remotely sensed data along with Survey of India Topographical and collateral information with necessary ground check helps in generating the base line information for ground water targeting.

\section{Role of remote sensing and GIS}

Spatial, spectral and temporal availability of data coverage.

Inaccessible areas can be covered.

Efficient and economic technology for broad range.

Assessing, monitoring and conserving groundwater resources.

Consistent, routine and global measurement.

GIS is powerful environment for real time database development.

\section{Remote sensing and GIS for groundwater zoning}

Different hydrogeological themes can be used to identify the groundwater potential zone. Geology, geomorphology, soil, lineament density, rainfall and land use/land cover maps are used to indicate the occurrence of groundwater. 
High resolution satellite imageries are widely used.

RS data with topographical sheets and collateral information with ground truth verifications help in generating baseline information for groundwater targeting.

Overlay analysis by GIS technique is used to delineate the groundwater potential zone.

\section{Materials and Methods}

\section{Data Required}

Topographic maps

Land use and land cover map

Lineament map

Drainage map

Soil information

Slope

Rainfall data

\section{Data collection}

Landsat TM data, IRS-IC, LISS-III Digital data images and SRTM (DEM) have been used. Survey of India (SOI) Toposheet at 1:50,000 scales have also been used.

Secondary data on hydrology and ground water well data have been collected from Central Ground Water Board and from the field to support mapping.

Geographic Information System and Image Processing (ARC VIEW, ARC GIS and ERDAS IMAGINE software) have been used for analysis and mapping of the individual layers as described in the flow chart.

\section{Satellite data analysis}

The main task in this stage was to carry out analysis and interpretation of satellite data, in order to produce thematic maps, such as lithology, structural and land use maps. Initially, all the images were rectified using the SOI Toposheet. This was followed by processing the digital images using the various processing techniques, viz., enhancement, filtering, classification and other GIS processes. Subsequently, selective field checking was carried out.

\section{Spatial database building}

The main task is to bring all the appropriate data and other collateral data together into a GIS database. All the available spatial data was assembled in the digital form and properly registered to make sure the spatial component overlaps correctly. Digitizing of all the maps and collateral data, followed by transformation and conversion from raster to vector, gridding, buffer analysis, box calculation, interpolation and other GIS processes were undertaken.

This stage produced derived layers of map such as Geomorphology, Drainage, Drainage density, Lithology, Lineament density, Surface water body, Slope etc.

\section{Spatial data analysis}

In this stage, the entire input layers derived from stage 2 and 3 were processed to extract the spatial features which are relevant to the groundwater zone. This stage includes various analyses such as table analysis and classification, polygon classification and weight calculation. Polygons in each of the thematic layers were categorized depending on the recharge characteristics, and suitable weightage have been assigned to them.

\section{Satellite data interpretation}

The final stage involved combining all thematic layers using the method that are modified from DRASTIC model. 


\section{Generalized Procedure for Potential Groundwater Zone}

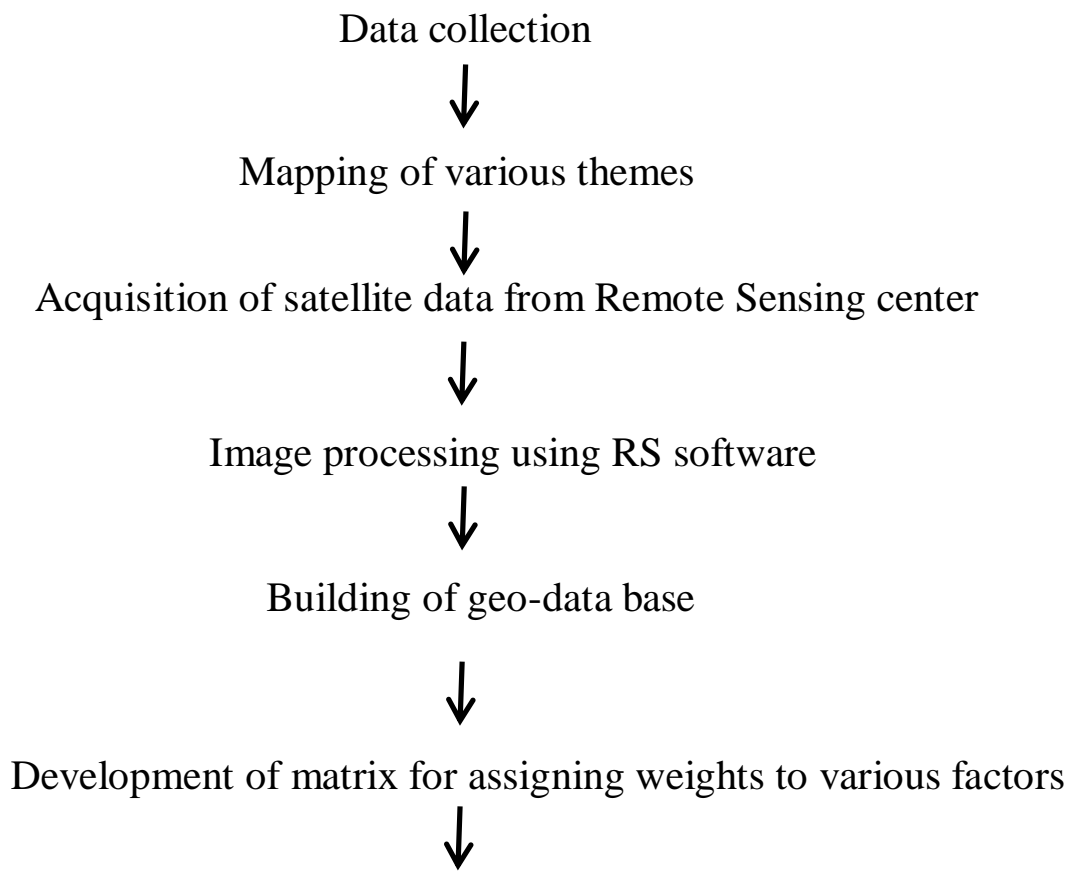

Ranking of the hydrogeological unit based on integration of all thematic layers

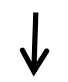

Overlay analysis by GIS technique

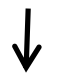

\section{Groundwater Potential Map}

This model is used to assess ground water pollution vulnerability by Environmental Protection Agency of the United State of America. The output has been classified into five groups such as very high, high, moderate, low and very low using the quantile classification method. Groundwater potential index (GWPI) in the present study has been determined by the formula as shown below:

$\mathrm{GWPI}=\sum_{i=1}^{i=n} W i * X i$

Where,

GWPI = groundwater potential index,
$\mathrm{W}_{\mathrm{i}}=$ weight for each map score, $\mathrm{X}_{\mathrm{i}}=$ rank of individual map.

\section{Weighting of thematic maps}

Reclassification is done in the ArcMap according to the importance of each factor.

Reclassification of land use/cover based on their character to infiltrate and to hold water.

Drainage density raster is reclassified based on the recharge potential.

Pairwise comparison and weight calculation for slope. 
Reclassified map of lineament - areas closer to lineaments have high porosity.

Reclassification of lithologies - based on susceptibility of the rock to weathering.

Contact density map - act as conduit of groundwater movement.

\section{Integration of thematic maps}

Different polygons are labelled separately and then registered.

Each polygon is designated based on groundwater occurrence and weights.

Final thematic layer is decided on the basis of probability level of occurrence that is assigned to each polygon.

\section{Factors influencing groundwater}

\section{Lithology map}

Lithology is a very important aspect in predicting groundwater potential zones. Extraction of geological information from satellite data depends on the identification of different patterns on an image resulting from the spectral arrangement of different tones and textures.

Depending on the rock reflectance properties, satellite images are used and they play important role in rock identifications. A lithology map is prepared using the IRS IC and Landsat TM Digital Data and simultaneously ground check verification is done in field.

\section{Geomorphology map}

Geomorphological map is prepared based on visual interpretation of Landsat TM and IRS LISS-III data on 50:000 scales and the geohydrology characters of the study area. Using the photogeologic elements21, viz., tone, texture, shape, size, association etc. the various geomorphological units have been demarcated.

\section{Slope map}

Slope always plays a crucial role in groundwater potential mapping. Using the SOI Toposheet and SRTM data of the area, a slope map of the area is prepared. The area, in general is very gentle slope. However, in the north-eastern part of the study area, there is an increase in slope.

Despite of this very gentle slope, a slope map has been prepared according to the following class interval.

\section{Surface water body map}

Surface water body map is prepared from Landsat TM Satellite data. The supervised maximum likelihood classification 22 is used to delineate the surface water body present in different parts of the area.

The study area is covered by many water logged bodies, ponds, lakes and rivers.

\section{Drainage map}

A surface drainage map is prepared from SOI Toposheet at 1:50,000 scale and satellite data. The study area is covered by Rushikulya and Bahuda River. Mostly the drainage pattern is dendritic in nature but locally it exhibits structurally controlled area.

\section{Drainage density map}

From the above Drainage map, a density map is generated. In this density map, the values have been assigned depending on the density of the drainage pattern. 


\section{Lineament map}

A surface lineament map is prepared from the SRTM DEM data. The study area exhibits a structurally controlled region. The areas have much high altitude hilly structures which are linearly aligned.

\section{Integration of thematic layers and modeling through GIS}

\section{Weighted index overlay model}

Depending on the groundwater potentiality, each class of the main eight thematic layers (geomorphology, lithology, slope, drainage density, lineament density and surface water body) are qualitatively placed into one of the following categories viz., (i) Excellent, (ii) Very good, (iii) Good, (iv) Moderate, (v) Poor.

Suitable weightage on a scale of 'Six' has been given to each class of a particular thematic layer based on their contribution towards ground water potentiality. The rank of each thematic map is scaled by the weight of that theme. All the thematic maps are then registered with one another through ground control points and integrated step by step using normalized aggregation method in GIS for computing groundwater potential Index of each feature. The weight assigned to different classes of all the thematic layers and rank of each features are given. All the thematic maps have been integrated using GWPI formula in GIS. A final groundwater potential map is prepared based on the above technique.

Integration of GIS and remote sensing techniques provides an excellent tool for delineation of potential ground water zones.

Analysis using geospatial tools can be undertaken with minimal time, high accuracy and lower costs.
Groundwater zones provide detailed hydrogeology and geophysical investigations needed for construction of wells and its proper management.

Water scarcity of the area can be minimized by construction of rain water sheds/tanks, reservoir and dams.

Delineated groundwater zones of the area can be used for ground water pollution studies, recharge sites and groundwater modeling.

\section{References}

Arkoprovo B., Adarsa J., Prakash S. S., 2012. Delineation of Groundwater Potential Zones using Satellite Remote Sensing and Geographic Information System Techniques: A Case study from Ganjam district, Orissa, India. Res. J. Recent Sci. ISSN 2277-2502.

Chuma C., Orimoogunje O. O. I., Hlatywayo D. J., Akinyede J. O., 2013. Application of Remote Sensing and GIS in Determining the Groundwater Potential in the Crystalline Basement of Bulawayo Metropolitan Area, Zimbabwe. Scientific Research, Advances in Remote Sensing, vol. 2, 149-161.

Deng F., Deng Z., Dan Lv, Wang D., Duan H., Xing Z., 2016. Application of remote sensing and GIS analysis in groundwater potential estimation in west Liaoning Province, China. Journal of Engg. Research, Vol. 4 No. (3), pp. $1-17$.

Gnanachandrasamy G., Yongzhang Zhou, Bagyaraj M., Venkatramanan S., Ramkumar T., Shugong Wang, 2018. Remote Sensing and GIS Based Groundwater Potential Zone Mapping in Ariyalur District, Tamil Nadu. Journal Geological Society of India, Vol.92, pp.484-490. 
Hutti. B., Nijagunappa. R., 2011. Identification of Groundwater Potential Zone using Geoinformatics in Ghataprabha basin, North Karnataka, India. IJGGS, Vol 2, No 1, ISSN 09764380.

Mukherjee P., Singh C. K., Mukherjee S., 2012. Delineation of Groundwater Potential Zones in Arid Region of India - A Remote Sensing and GIS Approach. Water Resource Manage 26:2643-2672. Pothiraj P., Rajagopalan B., 2011. A GIS and remote sensing based evaluation of groundwater potential zones in a hard rock terrain of Vaigai sub-basin, India.
Arab J Geosci, DOI 10.1007/s12517011-0512-3.

Venkateswarana S., Ayyanduraib R., 2015. Groundwater Potential Zoning in Upper Gadilam River Basin Tamil Nadu. International Conference on Water Resources, Coastal and Ocean Engineering (ICWRCOE 2015), Aquatic Procedia 4; 1275 - 1282. www.sciencedirect.com.

Waikar M.L., Nilawar A. P., 2014. Identification of Groundwater Potential Zone using Remote Sensing and GIS Technique. IJIRSET, Vol. 3, Issue 5, ISSN: 2319-8753.

\section{How to cite this article:}

Laulina Kumari. 2018. Delineation of Potential Groundwater Zone Using RS and GIS: A Review. Int.J.Curr.Microbiol.App.Sci. 7(12): 196-203. doi: https://doi.org/10.20546/ijcmas.2018.712.025 